\title{
Website for Solving Hyperreality of Indonesian Village Government Budget
}

\author{
Wita Ramadhanti \\ Jenderal SoedirmanUniversity \\ witarama.akuntan@gmail.com* \\ Sri Wijayanti \\ Jenderal SoedirmanUniversity \\ yantietaslim@yahoo.com
}

\author{
Tyas R. Wulan \\ Jenderal Soedirman University \\ tyashzul@yahoo.com \\ Dalhar Shodiq \\ Jenderal SoedirmanUniversity
}

\begin{abstract}
There are sudden shift in Indonesia village law in 2014. The villages that usually "forgotten", now empowered fully by central government. Village organization have to make radical structural change in organization body, budget and accounting. This change will be analyses with qualitative approach using critical-postmodernism approach. Informants are village governments in Banyumas Region, Central Java, Indonesia.

The analysis shows that there is hyperreality about village capacity, which the "flood" of the budget coming from higher government transfer fund not from village real income rises. Overall, the change in village organization is mostly about topdown not bottom-up like it used to be. If this change is not followed by capacity building for village people, the change only wasting money. Building villages' website is one innovative way to gather public participation and also disseminate public information between village governments to village people.
\end{abstract}

Keywords: hyperreality, village government, budget, and website

\section{I.INTRODUCTION}

There are radical changes in Indonesia village government due the issuance of Undang-undang Number 6/ 2014. The villages that usually "forgotten" empowered fully by central government. It should experience a big change the organization body, the authority, and point a view about development.

The smallest government body in Indonesia consist of village and kelurahan. Kelurahan is an administrative authority, run by government official men, and located in the city district. Village is a rather autonomous authority, run by head of the villages' team which is elected by citizen, helped by one government official man, and located in the rural area. Living in kelurahan usually much more prosperous rather than in village because it has better access to healthcare, education, and job.
Despite that, many people still choose to live in village due to the origins of their ancestor.

The village law have been implementing in 2015. Villages' government now are independent democratic unit. It run by government select directly by citizen, without any of government officials men. The citizen have representative such as parliament in the village level. Every village suddenly have enormous budget, more ten times it used to be since this country independence. This villages have to make development planning, revenue generating unit, as well as reporting the budget usage with the help of citizen participation in budget process.

The problem is the administrative system to make planning, budgeting, and reporting is beyond villagers' capacity. The system are usually for highly educated people, while in the village mostly low educated. This is also difficult to change villagers' perspective which usually dictating by higher authority government into participative development. This rapid social changes that seems unrealistic could drive into hyperreality (Baudrillard, 1998: 171) that is welfare village community will never be achieved.

This research wants study several things. First, it want to know the villages' official point of view of the process changes. Second, it would make critics on the conditions experiences by villagers'. Third, it then trying to make solution by helping villages developed official website to gather and disseminate information with its citizen.

\section{II.JEAN BAUDRILLARD HYPERREALITY}

Hyperreality is one of popular critical postmodernist theory. Hyperreality is a stage of cultural changes where there are transition between conservatives and routines life into mass culture that mediates by technology such as televisions and computers (Smith, 2010: 95). Its stages are simulacrum, implosion, hyperreality (Macintosh and Shearer, 2000). 
Sign, model, image are example of simulacrum (Macintosh and Shearer, 2000). Implosion is a condition when a new conditions emerges and the boundaries between old one gradually dissolves (Smith, 2010: 96). Hyperreality are a condition where simulacra no longer associate with reality (Macintosh et al., 2000). In other word, it already create illusion that are far beyond reality (Smith, 2010: 96).

There are 4 types of sign (Macintosh and Shearer, 2000). First, sign which is really associates with real objects. Second, is a sign that starting is create unclear or partially hide real image to the reader. Third, a sign that hides the real objects. Fourth, an images that is really detached from the real objects.

This theory then adopt in accounting and finance area. Machintosh and Shearer (2000) shows that conventional accounting model are an example of simulacra. Implossion example are the difference between operating and financial income to hide activity that might will cause loss in the short term but will create sustainable income in the future. Hyperreality example are covenants liability, such as a condition where a company give warranty to attracts customers but afraid of loss due to fulfill this promise.

Study on credit failure in Hongkong by Fung (2009) shows that hyperreality exist in this area. Simulacra is the condition where people buying a big house that they actually cannot pay using credit as a sign of higher status in society. This is a sign of consumer world value implodes. It became hyperreality when many people that doing the same things finally failed to pay their mortgage and lead the world to credit crisis.

Study on external funding in public sector are shows the same pattern. Rudkin (2005) finding that government funding in Australian public university only a simulacra of politics accountability. This is one way government shows that they care about public education needs, but actually they only need to make citizen politically vote for government. Pasoloran et al. (2015) in Indonesian Local government budget shows that politician uses aspiration funds just to get political support for them.

\section{III.RESEARCH METHODOLOGY}

This is a qualitative research. Informant are village governments in Cilongok District, Banyumas Region, Central Java, Indonesia. This research choose Cilongok district because it is the largest District in Banyumas (Bappeda Banyumas, 2014).

Data are taken using focus group discussions with the Villages' government men and the head of the district. Analysis uses in this study are critical-postmodernist approach. This methods employed because this research not only gathered data than criticized it, but also reflect it find out the solution (Riduwan et al., 2010).

\section{IV.HYPERREALITY IN VILLAGE GOVERNMENT BUDGET AND STRUCTURAL CHANGES}

Based on data collection the condition before implementation of Village, the village is lack of money and infrastructure. The induction of Village law then create a hyperreality. Here are the proof that there are the stages of hyperreality in village organizational changes.

\section{A.Simulacra}

Cilongok district contains 20 villages, the largest in Banyumas. Therefor it only have 1 senior high school and have no hospital (only clinics available). Accepting a lot of money means this village have to open bank account, but there are only 1 bank available in Cilongok District (Bappeda Banyumas, 2014). As consequences of lack public service conditions, there are more people choose to move out from Cilongok rather than move in (BPS Banyumas, 2015).

Total district real income in $2013 \mathrm{Rp} 13,718,300.00$ and in

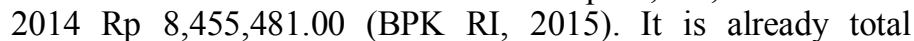
income from all village and district in Cilongok. Imagines if $\mathrm{Rp}$ $8,455,481.00$ are income from 20 villages, then each actually earns $\mathrm{Rp}$ 422,774.05. This means that before the implementation of the law the condition villages in Cilongok is low income.

This statististical data is a sign of simulacra, sign which is really associates with real object. A sign that Cilongok is "not welfare". Not welfare maybe but also not consumeristic, it means that life is not derived only by money. Consumer value, even though look good on paper it could be dangerous in reality (Baudrillard, 1998).

It also a sign that even though it is not good in "consumer" indicator, it have other "value" that make people still lived in that place. It may something that is stated in Undang-undang Number 6/2014, a bless living in ancestor land with warm relations with extended family. They could fulfill needs with their own hand by having farm and livestock to family's daily consumption.

\section{B.Implosion}

Implementation of Undang-undang Number 6/2014, in the year of 2015 a village could have much more higher transfer income. This could lead to implosion, from non-material culture to capitalist one.

First, one serious consequences accepting rises in budget is the villages have to be ready finding their own income. Flypaper effect theory (Hines, Jr. and Thaler, 1995) states that a local government authority stated as healthy financial condition if at least $50 \%$ of their income budget coming from their own income, not from transfer income from higher authority. It means that if they want to accept up to $\mathrm{Rp} 1,000,000,000$ transfer budget, at least they have to boast their own income 2365 times! The fastest way to boost the local income is apply as much as tax as they could. It also make that public facility that usually care together becoming capitalist and ask them to pay because it is a "government aset", not a community belonging anymore. 
Second, village government have to make planning and calculating whether their performance will meet the "welfare criteria" or not. They should make planning that could be "marking" on yearly basic calculation. It would lead to the change from "socialist government" into "pure capitalist", which only doing project because it have good rate of return in terms of money. This project usually will choose the projects that have income in the short run rather than a holistic project that will remembering and stays for generations.

\section{C.Hyperreality}

Hyperreality is when the reality is all hidden. This is all the facility and looks great is there but this village government do not know how to get the transfer fund such as what Mr. Wa, a government team from JB Village states:

"We need routines updates information about law changing....the budget proposal and to make it could have real outcome."

When then the floor further asked whether they need training in making budget or also with accounting report, they are all answer:

"(We need) both!"

The logic actually villages that for long time had been marginalized now empowered through authority of enormous budge that could be use flexible according to their need. But the fact that to take this budget they need to make a difficult and bureaucratic planning, budgeting, and reporting beyond village government team's capability.

Overall this condition can be called as hyperfunctionalist a consumer culture (Baudrillard, 1998: 109). Government giving enormous money to the village government. The higher they could proposed the better hyperfunctionalist a consumer culture. The higher surplus and growth the better. It is been better "good in administrative process" rather than good in usefulness. Regardless the changing process making them happy or not.

\section{V.BUILDING VILLAGE WEBSITES: AN INNOVATIVE WAY TO MAINTAIN VILLAGE BUDGET HYPERREALITY}

Implementation of Villages Law make village governments have to change faster than ever. The have to find out what their people need. They also have to disseminate faster information about development to the villager. Building a village website is one way to solve it in information system era. Village changes from traditional into virtual are obvious with or without the implementation of Village Law.

\section{A.Simulacra}

Simulacra here is the real condition of Cilongok villages' infrastructure and facility in Information Technology is not good. Here are story from several village government team:

"Thieves took the fixed line communication cable" (Mr. Ax, head of the District)
"There are no fixed line communication cable in our village offices. Internet access using modem are very slow" (Mr. Az, KS village government team)

"There is an (internet) signal problem and there is no staff that could maintain the web" (Mr Kha, GL village government team)

This opinion means that the true conditions in Cilongok is not ready for having website. In Indonesia, fixed line telecommunication are monopoly by central government through Government Company namely PT Telkom. No fixed line cable is indicator of "underdeveloped" region. If they have fixed line cable but lost by theft and PT Telkom do not directly changes with new one, means that there means that a villages is not good in terms of "economic scales" for having revenue for the company.

Signal is a telecommunication using cellular phone provider. There are a several of privat provider in Indonesia. The more remote a village, the more difficult to get the signal. It also means not economical to build signal tower over there.

Maintaining the web itself need people that could do that. In the village it is difficult to find people who have IT ability. Mostly IT people will choose to stay in the city, and make it more difficult for village government to get this kind of staff.

\section{B.implosion}

Although the real conditions in Cilongok stated that they are not ready to implement IT, but there are still the virtual life are unstoppable. There are implosion in village website or social media building such follow:

"We have web that update about our tourist object. The problem is about routine update" (Mr. Az, KS village government team)

"7 villages already have village website, and 2 other have already have Facebook" (Mr Ax, head of the District)

It means that there are implosion about building website or its official social media such as Facebook. But there are the problems of update continuity. Since 9 from 20 villages have already had official sites, the rest of the villages agree to have training in activating official website hosting from Banyumas Region. The training not only consist of maintaining website, but also how to make planning, budget and reporting to funding the IT projects.

\section{C.Hyperreality}

At the end of the research all of the village already have official websites. Some of them already updates the conditions. Some of them already know what and how to proposed higher budget than last year, including budget to developing and maintaining its websites.

Baudrillard $(2010,96)$ stated that the seminal hyperreality terms are using for community changes due to the television and computers. It means that building village websites is also a hyperreality. But is that really a good village website and a good budget and its realization only hyperreality or will be embedded in real "growth" for village? 


\section{Conclusion \& Suggestion}

Radical changes suggest by Undang-undang 6/ 2014 is a hyperreality. It contain too fast organizational changes and too much budget raises, but too low human resources capacity to manages. One way to mitigating this hyperreality is building village website. The existence of the website is actually a hyperreality itself, but it could use to control the previous problems.

This research process are during first year implementation of Indonesia Village Law in 2015. The era where almost all of the informant experiencing "shock" due to the rapid changes. Further research could use longer time to collect data to derive deeper conclusions.

\section{REFFERENCES}

[1] Badan Pemeriksa Keuangan Republik Indonesia (BPK RI). 2015. Laporan Hasil Pemeriksaan atas Laporan Keuangan Pemerintahan Daerah Kabupaten Banyumas Tahun 2015. BPK RI, Jakarta.

[2] Badan Perencanaan Pembangunan Daerah Kabupaten Banyumas (Bappeda Banyumas). 2014. Kabupaten Banyumas dalam Angka 2014. Bappeda Banyumas, Banyumas.

[3] Badan Pusat Statistik Kabupaten Banyumas (BPS Banyumas). 2015. Statistik Daerah Kecamatan Cilongok 2015.

[4] Baudrillard, J. 1998. The Consumer Society: Myths and Structures. Sage, London, England.

[5] Baudrillard, Jean. 1988. Jean Baudrillard Selected Writing. Edited by Mark Poster. Retrieved from www.humanities.uci.edu/mposter at February 25, 2016.

[6] Fung, H. Y. Y. 2009. Comparing Jean Baudrillard's Hyperreality to Credit Crisis in 2008. Hong Kong Baptist University Paper.

[7] Hines, Jr. J. R. and R. H. Thaler. 1995. Anomalies The Flypaper Effect. Journal of Economic Perspectives Vol. 9 Number 4, Fall 1995, pp. 217226.

[8] Indonesian Government. 2014. Undang-undang Nomor 6 Tahun 2014 tentang Desa. Indonesian Government

[9] Macintosh, N. B. and T. Shearer. 2000. The Accounting Profession Today: A Poststructuralist Critique. Critical Perspectives on Accounting 11, pp.607-626.

[10] Macintosh, N. B., T. Shearer, D. B. Thornton, and M. Welker. 2000. Accounting as Simulacrum and Hyperreality: Perspectives on Income and Capital. Accounting, Organizations, and Society, pp. 13-50.

[11] Pasoloran, O., E. G. Sukoharsono, D. Said, and Y. Rura. 2015. Narcissism in Local Budgeting: The Mirror and Mask Effectsof Public Aspiration Fund. The International Journal of Accounting and Business Society, Vol. 23, No. 1, August 2015, pp. 73-96.

[12] Riduwan, A., I. Triyuwono, G. Iriyanto, and U. Ludigdo. 2010. Semiotika Laba Akuntansi: Studi Kritikal-Posmodernis Derridean. Jurnal Akuntansi dan keuangan Indonesia, Juni 2010, Vol. 7, No. 1, pp. 38-60.

[13] Rudkin, K. M. 2005. Australian School Funding and Accountability: History Imploding into the Present. Paper Wollongong University.

[14] Smith, R. G. 2010. Baudrillard Dictionary. Edinburg University Press, Edinburg. 